\title{
Records of kogiid whales in Namibia, including the first record of the dwarf sperm whale (Kogia sima)
}

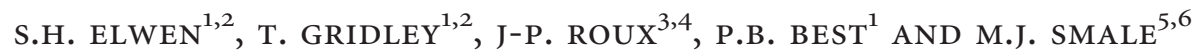

\begin{abstract}
${ }^{1}$ Mammal Research Unit, University of Pretoria, C/o Iziko South African Museum, Cape Town, 8ooo, South Africa, ${ }^{2}$ Namibian Dolphin Project, Walvis Bay, Namibia, ${ }^{3}$ Lu"deritz Marine Research, Ministry of Fisheries and Marine Resources, Shark Island, Lu“deritz, Namibia, ${ }^{4}$ Animal Demography Unit, Zoology Department, University of Cape Town, South Africa, ${ }^{5}$ Port Elizabeth Museum at Bayworld, PO Box 13147, Humewood, 6013, South Africa, ${ }^{6}$ Department of Zoology, Nelson Mandela Metropolitan University, PO Box 77000, Port Elizabeth, 6031, South Africa
\end{abstract}

Corresponding author: S.H. Elwen Email: simon.elwen@gmail.com

Dwarf (Kogia sima) and pygmy (K. breviceps) sperm whales occur in pelagic waters around southern Africa. Here we report the first record of K. sima from Namibia and provide information on the basic morphometrics and diet of that record and of two recent strandings of K. breviceps. All known records ( $1 / 429)$ of K. breviceps from Namibia are also collated. Eight families of cephalopod were identified in the stomach contents of the K. sima but no fish remains and few crustacean parts were present. Nine and ten families of cephalopod were identified in the stomachs of the two K. breviceps specimens respectively. This report expands the known range of K. sima by more than $1000 \mathrm{~km}$ from previous published records in the region. The sparsely populated nature of the Namibian coast and bias of records towards centres of human habitation suggest Kogia strandings are under reported. The low number of stranded specimens of K. sima from Namibia and west South Africa, in comparison to K. breviceps suggests that K. sima occur rarely or at very low densities in the area influenced by the Benguela current ecosystem. Specimens from Namibia are valuable due to uncertainties about taxomony of kogiids in the region.

Keywords: Kogia breviceps, Kogia sima, Namibia, dwarf sperm whale, pygmy sperm whale, new range state record, stomach contents, diet

INTRDDUCTION

The genus Kogia currently contains two recognized species, the dwarf (Kogia sima) and pygmy (K. breviceps) sperm whales. Due to their small body size, cryptic behaviour and small school sizes, these whales are difficult to observe at sea, and morphological similarities make field identification to species level problematic. The majority of what is known about kogiid whales in southern Africa (i.e. Namibia, South Africa and Mozambique) results from studies of stranded specimens (e.g. Ross, 1979a; Findlay et al., 1992; Plo“n, 2004), including preliminary evidence that $K$. sima inhabiting the Indo-Pacific and Atlantic Oceans may be separate species (Chivers et al., 2005). Documenting stranding events is valuable, as it is often the only access possible to rarely seen species. In addition, analysis of long term trends in stranding records may help to identify shifts in distribution such as those associated with environmental change (e.g. MacLeod et al., 2005; Weir et al., 2009; Salvadeo et al., 2010).

Kogia spp. are globally distributed in tropical and temperate oceans (Caldwell \& Caldwell, 1989), with K. breviceps usually extending into cooler waters than K. sima (see Baird et al., 1996; Willis \& Baird, 1998; Best, 2007 for review of distribution patterns). Both species are predominantly pelagic in their distribution occurring in deep oceanic waters off the shelf in tropical and temperate waters (Caldwell \& Caldwell,1989).

Around southern Africa, oceanic currents govern the temperature and productivity of the waters on the continental shelf and adjacent regions. These currents influence the species composition of these areas at all levels of the food chain, including marine mammals (Findlay et al., 1992; Ansorge \& Lutjeharms, 2007) and thus deserve some discussion within the context of new species records. The warm Agulhas Current flows south-westwards along the eastern seaboard of southern Africa from the Mozambique Channel to the southern most tip of the Agulhas Bank off South Africa, at which point the majority of the current retroflects back eastwards forming the Agulhas return current (Ansorge \& Lutjeharms, 2007) ( Figure 1). Eddies formed by meanders in the current sometimes break off forming 'Agulhas rings' which move north and west, bringing warmer waters and sometimes associated wildlife into the South Atlantic. The Benguela Current system is an eastern boundary upwelling system. Predominantly southerly winds move surface waters northwards and offshore, resulting in upwelling of cold waters and a northward flowing current. The Benguela ecosystem 


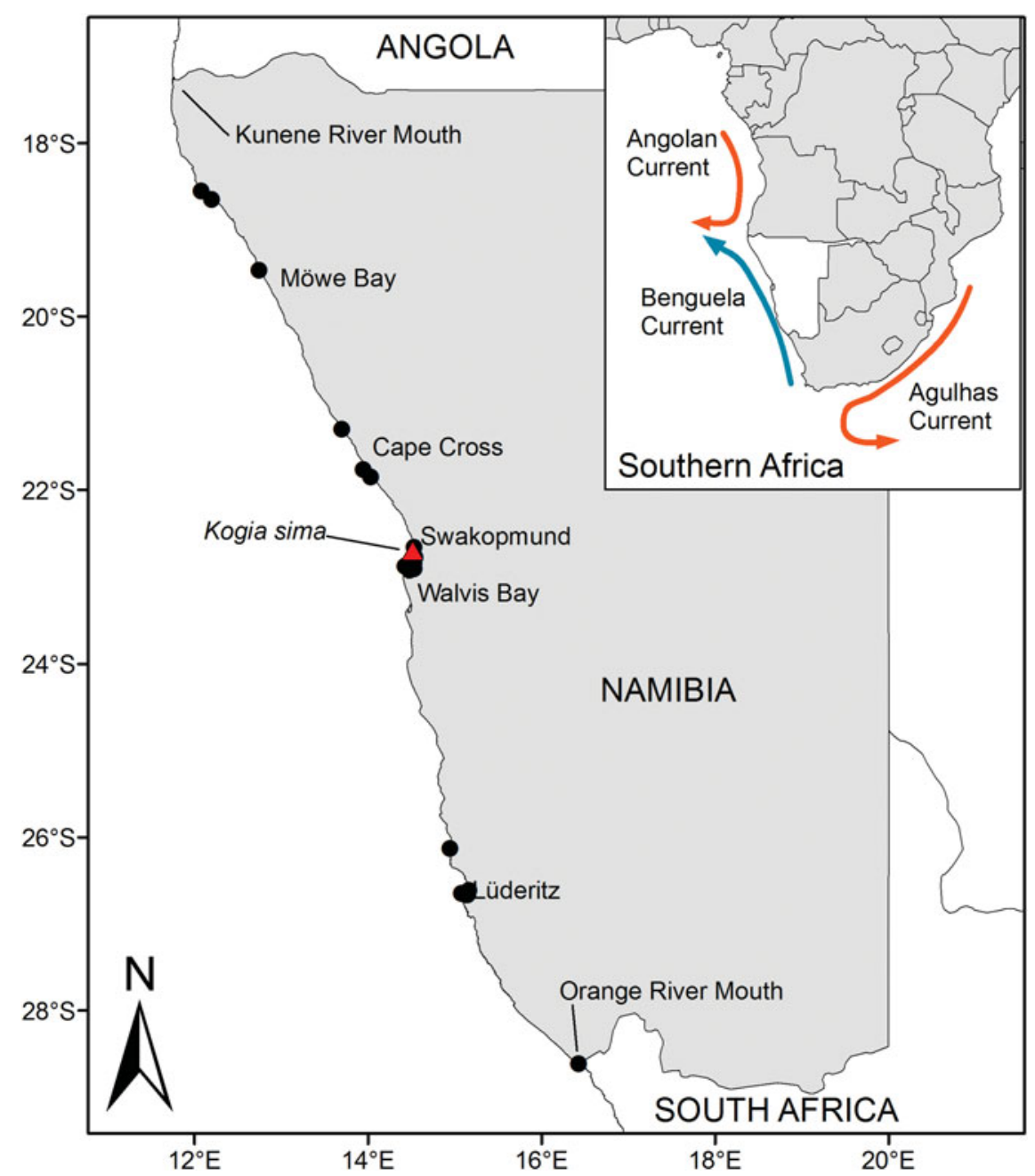

Fig. 1. Distribution of all known records of Kogia breviceps and Kogia sima in Namibia including places mentioned in text and main rivers at northern and southern borders. The Skeleton Coast National Park runs from the Kunene River to approximately 100 km north of Cape Cross.

is functionally split close to the South Africa-Namibia border due to an exceptionally strong upwelling cell in the Lu"deritz region in southern Namibia. The northern and southern Benguela have distinct oceanographic and cli-matic properties with the northern showing much greater sea-sonality and variation (Veitch et al., 2009). The northern boundary of the Benguela Current is formed by the Angola-Benguela frontal system, a dynamic boundary oscil-lating between $14^{\circ}$ and $17^{\circ} \mathrm{S}$ (Ansorge \& Lutjeharms, 2007). The western boundary of the Benguela Current system is more transient and ranges from roughly $200 \mathrm{~km}$ offshore in the south to $750 \mathrm{~km}$ offshore in the north, well off the continen-tal shelf (Wedepohl et al., 2000; Ansorge \& Lutjeharms, 2007). There are no published sightings records of live kogiids of either species in South Africa or Namibia. All that is known about their distribution patterns and habitat use within these countries is based on strandings records and extrapol-ations from at-sea sightings further afield in neighbouring countries (e.g. Best, 2007). Kogia breviceps have been recorded from strandings on both the east and west coasts of southern Africa (i.e. in both the Benguela and Agulhas Current systems), including Namibia and South Africa and from sight-ings in the tropical waters of the Indian Ocean (Ballance \& Pitman, 1998; Kiszka et al., 2010). No confirmed records (sightings or strandings) of $K$. breviceps are available in the Eastern Tropical Atlantic (Gulf of Guinea to Angola), north of Namibia (see Best, 2007; Van Waerebeek et al., 2009; Weir, 2010, 2011). Kogia sima has to date only been recorded from strandings along the warmer eastern coast of southern Africa, predominantly east of Cape Point (under the influence of the Agulhas Current), as far as the Comoros Islands (Kiszka et al., 2010) and into the Indian Ocean (de Boer et al., 2002). In the Atlantic, there is a notable absence of $K$. sima strandings or sightings from the area influenced by the Benguela ecosys-tem, with the exception of a few strandings in the southern

$\sim 100 \mathrm{~km}$, between St Helena Bay and Cape Point (Findlay et al., 1992). The northernmost record of $K$. sima within the Benguela is from $32^{\circ} 36^{\prime} \mathrm{S}$ (Plo"n, 2004; Best, 2007). Further north in the warmer waters of the Eastern Tropical Atlantic $K$. sima were seen exclusively in deep waters $(>900 \mathrm{~m})$ off Angola (while $K$. breviceps were never seen) during a series of predominantly deep water observations lasting $>5900$ hours of effort (Weir, 2011) as well as recorded from strand-ings in Ghana (Van Waerebeek et al., 2009).

Stomach contents analyses show that both Kogia species are predominantly teuthivorous (although some fish and crustacean species are also consumed) and that they have one of the most species rich diets of any small odontocete in southern 
Africa (Sekiguchi et al., 1992). Using specimens stranded within South Africa, Plo"n ( 2004) described the diet of K. breviceps to include 50 cephalopod, 12 fish and 5 crustacean species, while $K$. sima had a narrower diet range of 32 cephalopod, 3 fish and 3 crustacean species. Numerically, squid from the families Histioteuthidae and Lycoteuthidae were the most frequently taken by both Kogia species, while hake (Merluccius spp.) was the most frequently eaten fish genus (Plo"n, 2004).

This paper reports the first record of K. sima from Namibia and provides information on the basic morphometrics and diet of that record and of two recent stranded specimens of $K$. breviceps. All previously known records of the genus from Namibia are also collated. These data are presented and discussed within the context of known distribution patterns and environmental conditions within the southern African subregion.

\section{MATERIALS AND METHDDS}

Three Kogia spp. specimens, including one K. sima (KSo1) and two $K$. breviceps (KBo1 and $\mathrm{KBO2}$ ) stranded on the Namibian coastline between June and August 2010. A series of standard photographs and measurements (Geraci \& Lounsbury, 1993) were collected from all three individuals and field necropsies were conducted to investigate health status and collect biological samples (skin, blubber, ovaries and gastro-intestinal tracts) and skeletal material. The gastro-intestinal (GI) tract was removed and frozen for subsequent analysis of tract contents. Skeletal material (skull of KBo1, lower jaw of $\mathrm{KBo}$, the skull having been damaging during euthanasia, and the entire skeleton including skull of KSo1) were retained and are lodged in the Namibian National Museum, Windhoek (no accession numbers available as of submission).

\section{Dietary analysis}

The defrosted GI tract of each whale was opened and the contents of each stomach compartment passed through $425 \mu \mathrm{m}$ and $100 \mu \mathrm{m}$ mesh sieves. Nematode worms were separated from hard parts which included cephalopod beaks, eye lenses and crustacean carapaces. Hard parts and samples of nematode worms were stored in dilute ethanol prior to identification.

Beaks were counted, measured and identified by comparison with material in the Port Elizabeth Museum collections and using literature (Clarke, 1980, 1986; Smale et al., 1993). Effort was focused on lower beaks for identification and measurement as these are most used for species identification and allow comparison between studies (Clarke, 1986). Upper beaks were counted but not identified to species level. Dorsal mantle length (DML) and masses of each prey item were calculated from the lower beaks using either the rostral length (RL) for squid or crest length for Octopodiae and Sepiidae (Clarke, 1980, 1986; Smale, 1983; Smale et al., 1993). Only data from lower beaks are presented further.

\section{Records of Kogia spp. in Namibia}

All available records of Kogia from Namibia were compiled from multiple sources; all were stranded animals and no at sea sightings could be sourced. The majority of older records (prior to 1990) are held by the Whale Unit of the Mammal Research Institute, University of Pretoria (author: P.B.B.). Records made subsequent to this are held by the Namibian Ministry of Fisheries (author: J.P.R.) and more recently by the Namibian Dolphin Project (authors: S.E. and T.G.). Variable levels of detail are available for each record due to differences in the state of decay of each specimen and the manner by which it was recorded (attended for full necropsy, reported remotely, etc.). Much of the data resulting from records prior to 1990 has contributed to other studies including Ross (1979a, b), Findlay et al. (1992), Sekiguchi et al. (1992) and Plo"n ( 2004).

Species identification was based on one or more of the following criteria: external-relative dorsal fin height $(K$. sima: $>5 \%$ of total body length; K. breviceps: $<5 \%$ body length); relative position of dorsal fin from snout (K. sima: anterior insertion of dorsal fin is $>50 \%$ of body length from snout; $K$. breviceps: $<50 \%$ ), number and size of mandibular teeth ( $K$. sima: 8-11 pairs, $K$. breviceps: $11-17$ pairs); and cranial-dorsal cranial fossae cupped or uncupped, width of dorsal sagittal septum (Ross, 1979a; Best, 2007).

\section{RESULTS}

KSo1 live stranded on the 16 June $2010,5 \mathrm{~km}$ south of the town of Swakopmund $\left(22.7158^{\circ} \mathrm{S} 14.5279^{\circ} \mathrm{E}\right)$, but died in transit to the refloatation site. This is the first known occurrence of this species for Namibia and the northern Benguela ecosystem as a whole. KSo1 was a $216 \mathrm{~cm}$ long female, pregnant with a $6 \mathrm{~cm}$ long foetus. Dorsal height was $19.2 \mathrm{~cm}$ and girth at axilla of the flippers was $124 \mathrm{~cm}$. No external parasites were found, and the animal appeared in good health externally. One fresh bite on the dorsal ridge was possibly from a cookie cutter shark (Isistius spp.).

KBo1 was found freshly dead on the 24 August 2010 in the town of Lüderitz in the south of Namibia. KBo1 was a sexually immature female $228 \mathrm{~cm}$ long with a dorsal fin height of $10 \mathrm{~cm}$ and a girth at axilla of $139 \mathrm{~cm}$; ovaries were not collected due to failing light at the necropsy site. The animal had sustained multiple lacerations on the skin during stranding.

KBo2 live stranded on the 26 August 2010 in Guano Bay, Lüderitz, was refloated but restranded and was then euthanized. $\mathrm{KBo} 2$ was a $212 \mathrm{~cm}$ long, sexually immature female with a dorsal fin height of $9 \mathrm{~cm}$ and a girth at axilla of $132 \mathrm{~cm}$. Although appearing healthy and unscarred externally, $\mathrm{KBo} 2$ had a white lumpy swelling on the lung tissues and a large number of nematodes in the stomach (100s).

\section{Dietary analysis}

A summary of the prey identified in the stomachs of KSo1, $\mathrm{KBO} 1$ and $\mathrm{KBo} 2$ is presented in Table 1. Eight families of cephalopod were identified from the stomach of KSo1. The most numerous prey species taken by KSo1 were Sepiidae (cuttlefish) most likely Sepia australis, which also made up the largest proportion of the diet by mass. Nine and ten families of cephalopod were identified from $\mathrm{KBo} 1$ and $\mathrm{KBo} 2$ respectively. The most numerous prey taxa taken by KBo1 and KBo2 were Ommastrephidae (Ommastrephes bartrami) and Lycoteuthidae (Lycoteuthis lorigera) respectively. These species, as well as Octopoteuthidae (Octopoteuthis spp.) and 
Table 1. Cephalopod species identified from lower beaks in the stomachs of Kogia sima and Kogia breviceps stranded in Namibia, 2010. Beak rostral lengths shown are means for each species ( \pm standard deviation $(S D)$ where $\mathrm{N}>1$ ) with an overall mean of all lower beaks. Dorsal mantle length

(DML) and mass have been calculated from regression equations available in the literature and from existing collections held by the Port Elizabeth Museum. Regression values were obtained all from the literature (Clarke 1980, 1986), and Wolfe (1982) for Ommastrephes bartramii, and Cooper (1979) for Todaropsis eblanae. Regressions for Lycoteuthis lorigera were calculated from Port Elizabeth Museum material DML $(\mathrm{mm})=34.6 \times \mathrm{LRL}-21.93$ : mass $(\mathrm{g})=\mathrm{e}^{\wedge}\left(0.241+1.0155^{*} \mathrm{LRL}(\mathrm{mm})\right)$. Prey specimens have been identified as accurately as possible. Where confirmation of exact species was not confident (but genus was), we have indicated this with a '?'.

\begin{tabular}{lll} 
Specimen & Stomach & Family \\
\hline KSo1 & & \\
& Stomach 1 and oesophagus \\
& Histioteuthidae \\
& & Sepiidae \\
& Stomach 2 & Sepiidae \\
& & Chiroteuthidae \\
& Chiroteuthidae \\
& Cranchidae \\
& Histioteuthidae \\
& Histioteuthidae \\
& Lycoteuthidae \\
& Ommastrephidae \\
& & Onychoteuthidae \\
& & Empty
\end{tabular}

Genus/spp.
No Beak length (mm)

DML
$(\mathbf{m m})$
Mean mass (g) \pm SD
Total mass (\% contribution)

Totals

Stomach 1 and oesophagus Brachioteuthidae Chiroteuthidae Cranchiidae Histioteuthidae Histioteuthidae Histioteuthidae Lycoteuthidae Octopoteuthidae Ommastrephidae Ommastrephidae Pholidoteuthidae Sepiolidae

Stomach 2

Histioteuthidae Lycoteuthidae Ommastrephidae

Stomach 3

Histioteuthidae Lycoteuthida Ommastrephidae

Totals

KBo2

Stomach 1 and oesophagus Brachiotuethidae Brachiotuethidae Chiroteuthidae Cranchiidae Cranchiidae Cranchiidae Cycloteuthidae Histioteuthidae Lycoteuthidae Octopoteuthidae Ommastrephidae Ommastrephidae Onychoteurthidae Sepiidae

Stomach 2 Unidentified broken Stomach 3

Empty Sepia australis?

Sepia australis?

Chiroteuthis cf veranii Chiroteuthis joubini?

Taonius juvs

Histioteuthis miranda?

Histioteuthis macrohista

Lycoteuthis lorigera

Todarodes angolensis?

Moroteuthis

Brachioteuthis ?picta

Chiroteuthis Teuthowenia

Histioteuthis macrohista

Histioteuthis dofleini

Histioteuthis atlantica

Lycoteuthis lorigera

Octopoteuthis

Ommastrephes bartramii

Todaropsis eblanae?

Pholidoteuthis boschmai

Sepiolid

Histioteuthis juv?

Lycoteuthis lorigera

Ommastrephes bartramii

Histiotuethis macrohista

Lycoteuthis lorigera

Ommastrephes bartrami

19

$\begin{array}{rl}1 & 2.8 \\ 5 & 4.7(0.5) \\ 180 & 4.8(0.6) \\ 2 & 4.3(0) \\ 1 & 4.2 \\ 3 & 3.6(0.3) \\ 2 & 5.0(0.1) \\ 10 & 3.9(0.5) \\ 2 & 4.2(0.9) \\ 4 & 3.3(1.3) \\ 1 & 5.7 \\ & \\ 111 & 4.7(0.7)\end{array}$

49

$\stackrel{49}{-}$

53.1

$25.4(6.6)$

$53.1(0.7)$

$2114.7(0.7)$

$\begin{array}{rr}- & 27.7(8.7) \\ 116.6 & 40.3(0.0) \\ 114.1 & 37.9 \\ 208.8 & 36.4(5.7) \\ 97.5 & 202.8(13.2) \\ 72.4 & 114.3(32.0) \\ 121.7 & 105.5(86.3) \\ 125.2 & 84.5(98.7) \\ 221.4 & 473.3\end{array}$

$114 \cdot 3$

$37.7(43.7)$

7972.7

$$
\begin{array}{rl}
1 & 2.9 \\
2 & 4.9(0.8) \\
4 & 5(1.4) \\
34 & 2.8(0.5) \\
6 & 2.4(0.9) \\
8 & 3.6(0.4) \\
62 & 4.9(0.7) \\
9 & 9.5(1.8) \\
88 & 5.8(1.8) \\
18 & 3.1(0.7) \\
1 & 7.6 \\
1 & 2.5 \\
& \\
1 & 1.6 \\
2 & 4.7(0.1) \\
1 & 5.1
\end{array}
$$

$$
\begin{array}{ll}
1 & 3 \\
3 & 4.1(1.2) \\
1 & 6.1
\end{array}
$$$$
243 \quad 4.8(1.9)
$$

74.8
130
214.1
49.6
39.7
65.8

$$
7.8
$$

$57.5(24.2)$

$95.7(51.2)$

$57.2(18.6)$

$44.2(45.1)$

$94.7(21.8)$

$147,3 \quad 213,0(83.3)$

$163.8 \quad 222.9(91.7)$

$212.3 \quad 260.6(134.8)$

$117.6 \quad 61.0(35.5)$

$323.6 \quad 825.2$

$$
0
$$

5

21.9

139

193.5

14.6

$143.2(10.3)$

182.5

\section{$53 \quad 62.3$}

62.3

$121.1 \quad 123.6(90.3)$

$221.1 \quad 264.3$

151.2

$$
\text { 186.7 (139.6) }
$$

101.1

50.6

121.5

265.1

190.4

175.1

282.1

63

143.2

145.6

238.1

179

305.7

-

210.5

13.1

$3.7(0.2)$

45.6

$172.1(159.3)$

30.6 (11.3)

35.7 (2.6)

490.8

$87.3(23.5)$

$194.8(87.8)$

162.7 (18.9)

$332.8(115.1)$

165.8 (32.7)

aropsis eblanae

Sepia sp.

Unidentified broken

15
749.4

22.8

$66.2(60.8)$
$7.8(0.1)$

$114.9(0.8)$

383.8 (2.7)

$1944.5(13.5)$

$265.1(1.8)$

$757.7(5.3)$

$1516.0(10.5)$

2006.4 (13.9)

4310.6 (29.9)

$1097.8(7.6)$

$825.2(5.7)$

$5.0(0.03)$

$14.6(0.1)$

$286.4(2.0)$

182.5 (1.3)

$62.3(0.4)$

370.7 (2.6)

264.3 (1.8)

14414.7
13.1 (0.1)

14.7 (0.1)

$45.6(0.3)$

$344.3(2.3)$

$61.1(0.4)$

$71.3(0.5)$

$490.8(3.3)$

349.1 (2.3)

$6233.4(41.6)$

650.9 (4.3)

4991.9 (33.4)

$663.3(4.4)$

$749.4(5.0)$

22.8 (0.2)

265.0 (1.8) 
Histioteuthidae (Histioteuthis atlantica) made the largest contribution by mass. The estimated length and mass of prey taken by the $\mathrm{KBO} 1$ and $\mathrm{KBo} 2$ were considerably larger than those taken by KSo1.

Nematode worms constituted a large proportion of the stomach contents (numbering thousands of individual worms and far outweighing the cephalopod beaks) in at least one of the three stomach cavities of all three animals examined-these samples will be analysed and discussed elsewhere. Other than parasites, the majority of food remains were cephalopod beaks, partly digested cephalopoda (tentacles, pens, eye lenses, etc) and some crustacean hard parts which were too degraded to be identified to species level. No fish otoliths were found in any of the stomachs. Differences in rate of digestion may play a role in the relative abundances of fish and cephalopod prey.

\section{Records of Kogia spp. in Namibia}

All previous records $(\mathrm{N}=29)$ of $K$. breviceps strandings within Namibia are presented in Table 2 and Figure 1. The majority of records originate near the coastal towns of Lu"deritz and Walvis Bay reflecting human habitation patterns along the Namibian coast (Figure 1). Three skulls found without any associated data in the Mo"we Bay Museum in 2010 are not included as they might represent some of the specimens recorded in a visit to the same museum by P.B.B. in 1986 or reported subsequently to him from the same general locality (i.e. records numbers $17-19$ in Table 2).

\section{DISCUSSIDN}

Due to their cryptic nature, studies of free ranging kogiid whales are difficult and rarely conducted. However, they are one of the most commonly stranded cetacean species globally (Cadona Maldonado \& Mignucci Giannoni, 1999; Maldini et al., 2005) and in southern Africa (Findlay et al., 1992, Plo“n, 2004). Consequently, much of what we know originates from strandings data. However, there are several biases associ-ated with using strandings data to infer distribution and natural history, which must be considered.

Survey effort and reporting of strandings may be spatially or temporally biased, related to the density of human habitation, meteorological or oceanographic influences (Brabyn \& McLean, 1992; Wright, 2005; Hart et al., 2006; Witt et al., 2006). Stomach contents might not be truly representative of diet (Sekiguchi et al., 1992). Strandings records may not accurately reflect the species composition at sea; for example, although $K$. breviceps was the more common of the two Kogia species stranding on the Hawaiian Island chains, sightings surveys at sea showed the opposite pattern with $K$. sima making up 13 of 14 groups seen (Baird, 2005). However, in the absence of other forms of data collection, records of stranded animals are highly valuable sources of data (Findlay et al., 1992; McLellan et al., 2002; Maldini et al., 2005; Elwen et al., 2011).

This is the first report of $K$. sima in Namibia and our record extends the known species range by more than $1000 \mathrm{~km}$ from previous published sightings or strandings records in southern Africa. The closest published sightings and strandings of the species are in deep water $(922-2105 \mathrm{~m})$ off northern Angola (6-8 ${ }^{\circ} 46^{\prime}$ S; Weir, 2011) and along the very southern
Benguela coastline respectively $\left(32-34^{\circ} \mathrm{S}\right.$; Findlay et al., 1992; Best, 2007). However, there have been recent sightings of $K$. sima offshore of the town of Benguela in southern Angola (Caroline Weir, personal communication) at around $12^{\circ} \mathrm{S}$. This is at the extreme northern limit of what could be considered the Benguela ecosystem. The nearest presumed $K$. sima habitat to the site where KSo1 came ashore is the warmer oceanic waters off the continental shelf of Namibia (Best, 2007). The records to date suggest a hiatus in the distribution of $K$. sima between $12^{\circ} \mathrm{S}$ and $32^{\circ} \mathrm{S}$, possibly associated with the cool Benguela ecosystem along the west coast of southern Africa which may extend up to $750 \mathrm{~km}$ offshore in the northern areas (Wedepohl et al., 2000; Ansorge \& Lutjeharms, 2007). However, until dedicated cetacean surveys are conducted in these pelagic waters, we cannot conclude that $K$. sima is absent from this area.

Several factors may explain this new record but interpretation is hampered by the lack of scientific survey effort in pelagic waters or published sightings from platforms of opportunity such as are available for Angola (e.g. Weir, 2007). In addition, Namibia has a poor record of strandings along the coast with no official strandings response group and very low human presence along much of the coastline. Only

$\sim 50 \mathrm{~km}$ of coast around Lu"deritz and $\sim 200 \mathrm{~km}$ of coast north of Walvis Bay are readily accessible to members of the public. Human presence in the remainder of the Namibian coastline (more than $1500 \mathrm{~km}$ total length) is severely constrained by physical conditions, including around $400 \mathrm{~km}$ of dune fields, or mining and conservation related restrictions. However, these same limitations apply to the reporting of all species and we have collated 29 records of $K$. breviceps from the Namibian coast (which clearly reflect a bias towards centres of human habitation: Table 1; Figure 1). By comparison, in neighbouring South Africa the two species strand with similar frequencies; Plo"n (2004) listed a total of 106 specimens of $K$. breviceps and 85 specimens of $K$. sima (both coasts com-bined, although the vast majority of recorded strandings occurred south and east of St Helena Bay at $32^{\circ} \mathrm{S}$ ). The most parsimonious explanation for this novel record is that K. sima occurs rarely or at very low densities off the coast of Namibia, possibly because of the cold water temperatures in the Benguela region. Due to the paucity and uneven distribution of data, assessing changes in distribution patterns or seasonality of kogiid strandings in Namibia is not currently possible.

With the exception of Brachioteuthidae, all families of cephalopod prey found in the stomach contents of KSo1 had previously been recorded in the stomachs of $K$. sima stranded in southern Africa (Sekiguchi et al., 1992; Plo"n, 2004). Kogia sima is reported to have a less diverse diet than $K$. breviceps (Sekiguchi et al., 1992) and to feed on smaller prey at shallower depths (Willis \& Baird, 1998). These pat-terns were supported by the lower diversity and smaller size and of the prey in the stomach of KSo1 in this study. The dominance of Sepia ?australis prey supports previous sugges-tions that $K$. sima, particularly juveniles, may be distributed closer inshore than K. breviceps (Ross, 1979b; Plo"n, 2004) as this species is the most common cuttlefish found on the west coast of South Africa and Namibia (Roeleveld, 1998) and is important in the regional food web (Lipinksi, 1992; Lipinski et al., 1992; de Bruyn et al., 2005). Nevertheless, cephalopods associated with the continental shelf slope (e.g. Histioteuthidae, Lycoteuthidae and Ommastrephidae-see 
Table 2. All known records of Kogia breviceps stranded in Namibia. Condition of specimens given as: L (live stranding); F (fresh dead); D (decomposingdessicated); S (skeletal). Museum or Record Number refers to accessioned specimens at the Iziko South African Musem (ZM), Namibian National Museum (NNM), and those held in unaccessioned collections at the Lüderitz Museum (LM), or by co-authors (P.B.B. and J.P.R.). Source refers to person, group or paper where record was sourced (P.B.B.-Peter Best/Iziko South African Museum, Cape Town, South Africa), Ross-(Ross, 1979a), Sekiguchi-

(Sekiguchi et al., 1992), Plön-Plön (2004), J.P.R.-Jean-Paul Roux, NDP-Namibian Dolphin Project. Where described localities were not precise enough to calculate latitude and longitude, place names have been used.

No. Museum or Date No. Sex Condition Latitude Longitude Length Photographs Material Source Record No. (m)

\begin{tabular}{lllllllllll}
\hline 1 & - & October 1966 & 1 & - & & & $26^{\circ} 40^{\prime}$ & $15^{\circ} 09^{\prime}$ & Ca 3.66 & $\mathrm{Y}$ \\
2 & ZM $_{37126}$ & 1971 & 1 & - & S & $21^{\circ} 51^{\prime}$ & $14^{\circ} 02^{\prime}$ & Ca 3.05 & $\mathrm{~N}$
\end{tabular}

\begin{tabular}{|c|c|c|c|c|c|c|c|c|c|c|}
\hline- & $<1972$ & 1 & - & S & $21^{\circ} 46^{\prime}$ & $13^{\circ} 57^{\prime}$ & $\mathrm{U}$ & $\mathrm{N}$ & $\begin{array}{l}\text { Skull no } \\
\text { mandibles }\end{array}$ & P.B.B. \\
\hline ZM 37396 & 7 October 1975 & 1 & M & $\mathrm{L}$ & $22^{\circ} 55^{\prime}$ & $14^{\circ} 32^{\prime}$ & 2.41 & $\mathrm{Y}$ & Mandibles & $\begin{array}{l}\text { P.B.B./ } \\
\text { Sekiguchi }\end{array}$ \\
\hline $\mathrm{ZM}_{39220}$ & June 1978 & 1 & - & S & $22^{\circ} 53^{\prime}$ & $14^{\circ} 26^{\prime}$ & $\mathrm{U}$ & $\mathrm{N}$ & $\begin{array}{l}\text { Skull, no } \\
\text { mandibles }\end{array}$ & P.B.B. \\
\hline ZM 39215 & June 1978 & 1 & - & S & $22^{\circ} 53^{\prime}$ & $14^{\circ} 26^{\prime}$ & $\mathrm{U}$ & $\mathrm{N}$ & $\begin{array}{l}\text { Skull, no } \\
\text { mandibles }\end{array}$ & P.B.B. \\
\hline ZM 39214 & June 1978 & 1 & - & S & $22^{\circ} 53^{\prime}$ & $14^{\circ} 26^{\prime}$ & $\mathrm{U}$ & $\mathrm{N}$ & $\begin{array}{l}\text { Skull, no } \\
\text { mandibles }\end{array}$ & P.B.B. \\
\hline ZM 39947 & $25-31$ August 1978 & 1 & $\mathrm{~F}$ & $\mathrm{~F}$ & $22^{\circ} 47^{\prime}$ & $14^{\circ} 33^{\prime}$ & $\mathrm{U}$ & $\mathrm{N}$ & Skull & P.B.B./Plön \\
\hline ZM 39219 & June 1978 & 1 & - & S & $22^{\circ} 53^{\prime}$ & $14^{\circ} 26^{\prime}$ & $\mathrm{U}$ & $\mathrm{N}$ & Lower jaw only & P.B.B. \\
\hline- & July 1979 & 1 & - & S & Skeletor & Coast Park & $\mathrm{U}$ & $\mathrm{N}$ & Skull* & P.B.B. \\
\hline ZM 39941 & 1 August 1979 & 1 & - & $\mathrm{D}$ & $21^{\circ} 18^{\prime}$ & $13^{\circ} 42^{\prime}$ & 3.39 & $\mathrm{Y}$ & Skull & P.B.B./Plön \\
\hline ZM 39930 & 6 August 1979 & 1 & - & $\mathrm{D}$ & $22^{\circ} 46^{\prime}$ & $14^{\circ} 32^{\prime}$ & 2.46 & $\mathrm{Y}$ & Skull & P.B.B./Plön \\
\hline 13 & 5 December 1980 & 1 & - & $\mathrm{D}$ & \multicolumn{2}{|c|}{ Walvis Bay } & 3.05 & $\mathrm{~N}$ & Skull* & P.B.B. \\
\hline ZM 39945 & 31 August 1982 & 1 & $\mathrm{~F}$ & $\mathrm{~L}$ & $22^{\circ} 40^{\prime}$ & $14^{\circ} 32^{\prime}$ & 3.0 & $\mathrm{Y}$ & Skull & $\begin{array}{l}\text { P.B.B./ } \\
\text { Sekiguchi/ } \\
\text { Plön }\end{array}$ \\
\hline $\mathrm{ZM} 40472$ & 4 September 1984 & 1 & $\mathrm{~F}$ & S & $22^{\circ} 55^{\prime}$ & $14^{\circ} 32^{\prime}$ & 2.38 & $\mathrm{~N}$ & Skull & $\begin{array}{l}\text { P.B.B./ } \\
\text { Sekiguchi/ } \\
\text { Plön }\end{array}$ \\
\hline 16 & 23 June 1982 & 1 & $\mathrm{~F}$ & $\mathrm{~L}$ & $22^{\circ} 56^{\prime}$ & $14^{\circ} 29^{\prime}$ & $2.1-2.4$ & $\mathrm{Y}$ & None & P.B.B. \\
\hline- & 1982 & 1 & - & S & $19^{\circ} 28^{\prime}$ & $12^{\circ} 45^{\prime}$ & $\mathrm{U}$ & $\mathrm{N}$ & Skull & P.B.B. \\
\hline 18 & 16 May 1983 & 1 & - & $\mathrm{D}$ & $18^{\circ} 33^{\prime}$ & $12^{\circ} 05^{\prime}$ & $\mathrm{U}$ & $\mathrm{N}$ & Skull & P.B.B. \\
\hline- & 19 September 1989 & 1 & $\mathrm{~F}$ & $\mathrm{D}$ & $18^{\circ} 39^{\prime}$ & $12^{\circ} 12^{\prime}$ & 1.935 & $\mathrm{Y}$ & None & P.B.B. \\
\hline $\begin{array}{r}\text { PBB9015/ } \\
\text { JPR } 01\end{array}$ & 23 February 1990 & 1 & $\mathrm{~F}$ & $\mathrm{D}$ & $26^{\circ} 08^{\prime}$ & $14^{\circ} 57^{\prime}$ & 2.96 & $\mathrm{~N}$ & $\begin{array}{l}\text { Skull, gastro- } \\
\text { intestinal } \\
\text { tract }\end{array}$ & $\begin{array}{l}\text { P.B.B./ } \\
\text { Sekiguchi/ } \\
\text { Plön }\end{array}$ \\
\hline LM & $<1986$ & 1 & - & $?$ & \multicolumn{2}{|c|}{ Lüderitz area } & $\mathrm{U}$ & $\mathrm{N}$ & $\begin{array}{l}\text { Skull, no } \\
\text { mandibles }\end{array}$ & P.B.B. \\
\hline JPR 02 & 1 November 1996 & 1 & - & $\mathrm{D}$ & $22^{\circ} 51^{\prime}$ & $14^{\circ} 32^{\prime}$ & 2.94 & $\mathrm{~N}$ & Skull & J.P.R./H. Plarre \\
\hline JPRo3 & November 1996 & 1 & $\mathrm{~F}$ & $?$ & $28^{\circ} 37^{\prime}$ & $16^{\circ} 26^{\prime}$ & 2.36 & $\mathrm{U}$ & Skull & J.P.R. \\
\hline JPRo4 & 15 January 1998 & 1 & - & $\mathrm{D}$ & $21^{\circ} 45^{\prime}$ & $13^{\circ} 58^{\prime}$ & 2.26 & $\mathrm{~N}$ & Skull & J.P.R./H. Plarre \\
\hline JPRo5 & 16 May 1998 & 1 & - & S & $21^{\circ} 47^{\prime}$ & $13^{\circ} 57^{\prime}$ & & $\mathrm{N}$ & Skull & J.P.R. \\
\hline JPRo6 & 15 February 2000 & 1 & F (lact) & $\mathrm{F}$ & $26^{\circ} 40^{\prime}$ & $15^{\circ} 09^{\prime}$ & 2.42 & $\mathrm{U}$ & Skull & $\begin{array}{l}\text { J.P.R./ } \\
\text { J. Kemper }\end{array}$ \\
\hline JPRo7 & 10 April 2009 & 1 & - & $\mathrm{D}$ & $26^{\circ} 40^{\prime}$ & $15^{\circ} 09^{\prime}$ & 2.05 & $\mathrm{U}$ & None & $\begin{array}{l}\text { J.P.R./ } \\
\text { R. Rossler }\end{array}$ \\
\hline NNM & 24 August 2010 & 1 & $\mathrm{~F}$ & $\mathrm{~F}$ & $26^{\circ} 37^{\prime}$ & $15^{\circ} 10^{\prime}$ & 2.28 & $\mathrm{Y}$ & Skull, tissue etc. & N.D.P. \\
\hline NNM & 26 August 2010 & 1 & $\mathrm{~F}$ & $\mathrm{~L}$ & $26^{\circ} 39^{\prime}$ & $15^{\circ} 05^{\prime}$ & 2.12 & $\mathrm{Y}$ & Mandibles, tissues & N.D.P. \\
\hline
\end{tabular}

below) were also found in the stomach of KSo1 and suggest that this individual had also fed near the shelf edge. It is important to note that stomach contents might not be truly representative of diet (Sekiguchi et al., 1992), however no other data on diet are available for kogiids in southern Africa. All families of cephalopod found in KBo1 and $\mathrm{KBo} 2$ had been previously reported in the diet of $K$. breviceps in southern Africa (Plo“n, 2004). The predominant taxa found such as Lycoteuthidae, Histioteuthidae and Ommastrephidae occur at the shelf break or in oceanic waters.

Histioteuthidae are bathypelagic or meso-bathypelagic (Nesis, 1987) and are also prey of sperm whales (Physeter macrocephalus) (Clarke, 1980) and other odontocete and shark apex predators (Sekiguchi et al., 1992; Smale \& Cliff, 1998). Lycoteuthidae are important prey for a variety of predators (Lipinksi, 1992; Sekiguchi et al., 1992; Smale, 1996; Smale \& Cliff, 1998) and have been trawled at water depths between 300 and $900 \mathrm{~m}$ (Roeleveld et al., 1992). The high importance of Histioteuthidae and Ommastrephidae in the stomach contents of individuals described here supports Clarke's (1996) 
contention that these families are important to oceanic cetacean predators.

Southern Africa is recognized as a global hotspot of cetacean diversity (Pompa et al., 2011) and over 25 species of cetacean have been recorded in Namibian waters alone (Findlay et al., 1992; Best, 2007). However, almost nothing is known about the abundance, stock structure or conservation status of most species within the region (Elwen et al., 2011), which is particularly concerning in light of anthropogenic impacts on the marine environment, such as pollution, exploration and extraction of hydrocarbons and phosphate bearing sedi-ments, marine tourism and overfished resources. The docu-mentation of this first record of K. sima in Namibian waters highlights our lack of knowledge in this area. Dedicated surveys in offshore waters are necessary to determine distri-bution and relative abundance of this species.

\section{ACKNDWLEDGEMENTS}

S.E., T.G. and P.B.B. acknowledge Iziko South African Museum for logistic support in Cape Town. S.E. and T.G. thank Gwen Penry, the team of Oceans Research Interns, Rod Braby, E. and H. Brand, Walther Schafer, Charmaine Vosloo and the team at Mola Mola marine tours for their assistance in the attempted rescue and later necropsy of KSo1; Rene Rossler of Sedina tours in Lüderitz for reporting the stranding of KBo2; and John Paterson for facilitating the visit to the Möwe Bay museum by the N.D.P. P.B.B. acknowledges the support of the National Research Foundation, and the assistance of Rudi Loutit, Steve Braine, Roy Cruikshank, Barrie Rose, Kurt Kleyenstüber and Herman Oosthuizen in collecting or providing access to material. J.P.R. acknowledges Dave de Villiers, Heidrun Plarre and Jessica Kemper for assistance at strandings. This paper is a contribution to the SEACODE Research Group in Namibia. We thank Caroline Weir for her many useful comments in the review of this MS. This research received no specific grant from any funding agency, commercial or not-for-profit sectors.

\section{REFERENCES}

Ansorge I.J. and Lutjeharms J.R.E. (2007) The cetacean environment off southern Africa. In Best P.B. (ed.) Whales and dolphins of the southern African subregion. Cape Town: Cambridge University Press, pp. 1-13.

Baird R.W., Nelson D., Lien J. and Nagorsen D.W. (1996) The status of the pygmy sperm whale, Kogia breviceps, in Canada. Canadian Field Naturalist 110/3, 525-532.

Baird R.W. (2005) Sightings of dwarf (Kogia sima) and pygmy (K. breviceps) sperm whales from the main Hawaiian Islands. Pacific Science 59, $461-466$.

Ballance L.T. and Pitman R.L. (1998) Cetaceans of the western tropical Indian Ocean: distribution, relative abundance, and comparisons with cetacean communities of two other tropical ecosystems. Marine Mammal Science 14, 429-459.

Best P.B. (ed.) (2007) Whales and dolphins of the southern African subregion. Cape Town: Cambridge University Press.

Brabyn M. and McLean I. (1992) Oceanography and coastal topography of herd-stranding sites for whales in New Zealand. Journal of Mammalogy 73, 469-476.
Cadona Maldonado M. and Mignucci Giannoni A (1999) Pygmy and dwarf sperm whales in Puerto Rico and the Virgin Islands, with a review of Kogia in the Caribbean. Caribbean Journal of Science 35, $29-37$.

Caldwell D.K. and Caldwell M.C. (1989) Pygmy sperm whale Kogia breviceps (de Blainville, 1838): dwarf sperm whale Kogia simus Owen, 1866. In Ridgway S. and Harrison R. (eds) Handbook of marine mammals. Volume 4. River dolphins and larger toothed whales. London: Academic Press, pp. 235-260.

Chivers S., LeDuc R., Robertson K., Barros N. and Dizon A. (2005) Genetic variation of Kogia spp. with preliminary evidence for two species of Kogia sima. Marine Mammal Science 21, 619-634.

Clarke M.R. (1980) Cephalopoda in the diet of sperm whales of the Southern Hemisphere and their bearing on sperm whale biology. Discovery Reports 37, 1-324.

Clarke M.R. (1986) A handbook for the identification of cephalopod beaks. Oxford: Clarendon Press.

Clarke M.R. (1996) Cephalopods as prey. III Cetaceans. Philosophical Transactions of the Royal Society, London 351B, 1053-1065.

Cooper J. (1979) Length-mass relationships, water content and energy values of two species of squid, Loligo reynaudi and Todaropsis eblanae off the south-western Cape. Fisheries Bulletin of South Africa $11,43-45$.

de Boer M.N., Baldwin R., Burton C.L.K., Eyre E.L., Jenner K.C.S., Jenner M.N.M., Keith S.G., McCabe K.A., Parsons E.C.M., Peddemors V.M., Rosenbaum H.C., Rudolph P. and Simmonds M. (2002) Cetaceans in the Indian Ocean Sanctuary: a review. Paper $\mathrm{SC} / 54 / \mathrm{O}_{5}$ presented to the IWC Scientific Committee.

de Bruyn P.J.N., Bester M.N., Kirkman S.P., Mecenero S., Roux J.P. and Klages N.T.W. (2005) Cephalopod diet of the Cape fur seal Arctocephalus pusillus pusillus, along the Namibian coast: variation due to location. African Zoology 40, 261-270.

Elwen S.H., Findlay K.P., Kiszka J. and Weir C.R. (2011) Cetacean research in the southern African subregion: a review of previous studies and current knowledge. African Journal of Marine Science 33, 469-493.

Findlay K.P., Best P.B., Ross G.J.B. and Cockcroft V.G. (1992) The distribution of small odontocete cetaceans off the coasts of South Africa and Namibia. South African Journal of Marine Science 12, 237-270.

Geraci J.R. and Lounsbury V.J. (1993) Marine mammals ashore-a field guide for strandings. Galveston, TX: Texas A\&M Sea Grant Publications, $305 \mathrm{pp}$.

Hart K.M., Mooreside P. and Crowder L.B. (2006) Interpreting the spatio-temporal patterns of sea turtle strandings: going with the flow. Biological Conservation 129, 283-290.

Kiszka J., Ersts P.J. and Ridoux V. (2010) Structure of a toothed cetacean community around a tropical island (Mayotte, Mozambique Channel). African Journal of Marine Science 32, 543-551.

Lipinksi M.R. (1992) Cephalopods and the Benguela ecosystem: trophic relationships and impact. South African Journal of Marine Science $12,791-802$.

Lipinski M.R., Payne A.I.L. and Rose B. (1992) The importance of cephalopods as prey for hake and other groundfish in South African waters. South African Journal of Marine Science 12, 651-662.

MacLeod C., Bannon S., Pierce G., Schweder C., Learmonth J. and Reid R. (2005) Climate change and the cetacean community of north-west Scotland. Biological Conservation 124, 477-483.

Maldini D., Mazzuca L. and Atkinson S. (2005) Odontocete stranding patterns in the main Hawaiian Islands (1937-2002): how do they compare with live animal surveys? Pacific Science 59, 55-67. 
McLellan W.A., Friedlander A.S., Mead J.G., Potter C.W. and Pabst D.A. (2002) Analysing 25 years of bottlenose dolphin (Tursiops truncatus) strandings along the Atlantic coast of the USA: do historic records support the coastal migratory stock hypothesis? Journal of Cetacean Research and Management 4, 297-304.

Nesis K.N. (1987) Cephalopods of the world. Neptune City, NJ: TFH Publications.

Plön S. (2004) The status and natural history of pygmy (Kogia breviceps) and dwarf (K. sima) sperm whales off Southern Africa. PhD thesis. Department of Zoology \& Entomology, Rhodes University, South Africa.

Pompa S., Ehrlich P. and Ceballos G. (2011) Global distribution and conservation of marine mammals. Proceedings of the National Academy of Sciences of the United States of America 108, 13600-13605.

Roeleveld M.A.C. (1998) The status and importance of cephalopod systematics in southern Africa. In Cephalopod biodiversity, ecology and evolution. South African Journal of Marine Science 20, 1-16.

Roeleveld M.A.C., Lipinksi M.R., Augustyn C.J. and Stewart B.A. (1992) The distribution and abundance of cephalopods on the continental slope of the eastern South Atlantic. In Payne A.I.L., Brink K.H., Mann K.H. and Hillborn R. (eds) Benguela trophic functioning. South African Journal of Marine Science 12, 739-752.

Ross G.J.B. (1979a) Records of pygmy and dwarf sperm whales, genus Kogia, from southern Africa, with biological notes and some comparisons. Annals of the Cape Provincial Museum of Natural History 11, $259-327$.

Ross G.J.B. (1979b) The smaller cetaceans of the south-east coast of southern Africa. PhD thesis. Zoology Department, University of Port Elizabeth, Port Elizabeth. 415 pp.

Salvadeo C., Lluch Belda D., Gomez Gallardo A., Urban Ramirez J. and MacLeod C. (2010) Climate change and a poleward shift in the distribution of the Pacific white sided dolphin in the northeastern Pacific. Endangered Species Research 11, 13-19.

Sekiguchi K., Klages N.T.W. and Best P.B. (1992) Comparative analysis of the diets of smaller odontocete cetaceans along the coast of southern Africa. In Payne A.I.L., Brink K.H., Mann K.H. and Hillborn R. (eds) Benguela trophic functioning. South African Journal of Marine Science $12,843-861$.

Smale M.J. (1983) Resource partitioning by top predatory teleosts in the Eastern Cape coastal waters (South Africa). PhD thesis. Rhodes University, South Africa.

Smale M.J. (1996) Cephalopods as prey. IV. Fishes. Philosophical Transactions of the Royal Society, London 351B, 1067-1081.

Smale M.J., Clarke M.R., Klages N.T. and Roeleveld M.A.C. (1993) Octopod beak identification-resolution at a regional level
(Cephalopoda, Octopoda: Southern Africa). South African Journal of Marine Science 13, 269-293.

Smale M.J. and Cliff G. (1998) Cephalopods in the diets of four shark species (Galeocerdo cuvier, Sphyrna leweni, S. zygaena and S. mokarran) from KwaZulu-Natal, South Africa. South African Journal of Marine Science 20, 241-253.

Van Waerebeek K., Ofori-Danson P.K. and Debrah J. (2009) The cetaceans of Ghana, a validated faunal checklist. West African Journal of Applied Ecology 15, 61-89.

Veitch J., Penven P. and Shillington F. (2009) The Benguela: a laboratory for comparative modelling studies. Progress in Oceanography 83, 296302.

Wedepohl P.M., Lutjeharms J.R.E. and Meeuwis J.M. (2000) Surface drift in the south-east Atlantic Ocean. South African Journal of Marine Science 22, 71-79.

Weir C.R. (2007) Occurrence and distribution of cetaceans off northern Angola, 2004/05. Journal of Cetacean Research and Management 9, 225-239.

Weir C.R. (2010) A review of cetacean occurrence in West African waters from the Gulf of Guinea to Angola. Mammal Review 40, 2-39.

Weir C.R. (2011) Distribution and seasonality of cetaceans in tropical waters between Angola and the Gulf of Guinea. African Journal of Marine Science 33, 1-15.

Weir C., MacLeod C. and Calderan S. (2009) Fine scale habitat selection by white beaked and common dolphins in the Minch (Scotland, UK): evidence for interspecific competition or coexistence? Journal of the Marine Biological Association of the United Kingdom 89, 951-960.

Willis P. and Baird R. (1998) Status of the dwarf sperm whale, Kogia simus, with special reference to Canada. The Canadian Field Naturalist 112, 114-125.

Witt M.J., Penrose R. and Godley B.J. (2006) Spatio-temporal patterns of juvenile marine turtle occurrence in waters of the European continental shelf. Marine Biology 151, 873-885.

and

Wright A.J. (2005) Lunar cycles and sperm whales (Physeter macrocephalus) strandings on the North Atlantic coastlines of the British Isles and eastern Canada. Marine Mammal Science 21, 145-149.

\section{Correspondence should be addressed to:}

S.H. Elwen

Mammal Research Unit

University of Pretoria, C/o Iziko South African Museum, Cape Town, 8000, South Africa email: simon.elwen@gmail.com 


\section{CORRIGENDA}

MATERIALS AND METHODS:

Page 3, column 2, paragraph 2: Correct method to identify the two Kogia species from relative position of the dorsal fin from snout is: K. sima-anterior insertion of dorsal fin is $<50 \%$ of body length from snout; in K. breviceps it is $>50 \%$.

Page 3, column 2, paragraph 4: Sexual maturity of specimen KBo1 was additionally determined from body length after Best (2007).

Page 3, column 2, last paragraph: Sepiidae were the most numerous prey taxon (not species) taken by KSo1. Additionally, correct spelling of species name in family Ommastrephidae is Ommastrephes bartramii.

In Table 1, multiple species names were spelled incorrectly.

veranyi should be: veranii

bartrami should be: bartramii

Hystioteuethis should be: Histioteuthis Brachiotuethidae

should be: Brachioteuthidae (Family) Onychoteurthidae

should be: Onychoteuthidae (Family) Lycotuthis should

be: Lycoteuthis

spp. should be: sp.

juv? and juvs should be: juvenile

In Table 2, the asterisk on records 10 and 12 is not explained and should have the following text below table: Skull supposed to have been collected but whereabouts unknown.

Page 5, column 2, last paragraph: extra 'and' in the sentence should be disregarded and sentence should read: 'These patterns were supported by the lower density and smaller size of the prey in the stomach of KSo1 in this study'.

In the reference list, it must be noted that Best (2007) should be corrected to:

Best P.B. (2007) Whales and dolphins of the southern African subregion. Cape Town: Cambridge University Press.

\section{REFERENCES}

Best P.B. (2007) Whales and dolphins of the southern African subregion. Cape Town: Cambridge University Press.

and

Elwen S.H., Gridley T., Roux J.-P., Best P.B. and Smale M.J. (2013) Records of kogiid whales in Namibia, including the first record of the dwarf sperm whale (Kogia sima). Marine Biodiversity Records 6, e45, 8 pp. doi: http://dx.doi.org/10.1017/S1755267213000213. 